\title{
Spectrum of threats to nests of Yellow-wattled Lapwing Vanellus malabaricus in K urukshetra outskirts-a case study
}

\author{
R ohtash Chand G upta\# and T ir shem K umar K aushik* \\ Department of Zoology, Kurukshetra University, Kurukshetra (Haryana), INDIA \\ ${ }^{\text {\#S} S e n i o r ~ V i s i t i n g ~ F a c u l t y, ~ I n s t i t u t e ~ o f ~ E n v i r o n m e n t ~ S t u d i e s, ~ K u r u k s h e t r a ~ U n i v e r s i t y, ~ K u r u k s h e t r a-136119 ~(H a r y a n a), ~ I N D I A ~}$ \\ *Corresponding author. E-mail: tarshemkaushik@ rediffmail.com
}

\begin{abstract}
It is one thing that Red-wattled Lapwing Vanellus indicus is, rather a common bird on the outskirts of wheat harvested fields in outskirts of Kurukshetra, yet, Yellow-wattled Lapwing V. malabaricus (Boddaert, 1783) is an uncommon bird and seen rarely and that too with efforts and serious search. On the top of this, the bird is confronting most difficult conditions for its even rare existence. It is characterized by the presence of bright Yellow fleshy lappets above and in front of eyes. Black wings show off a white bar in flight. It has a little shorter stature compared with that of Red-wattled Lapwing. Yellow-wattled Lapwing is available in only very specific spots like Sushant City, Harman City and Sector-8 in isolated conditions as single, double or 6-8 in Kurukshetra environs. Only one nest of Yellow-wattled Lapwing was observed on 28 April, 2011 in Sushant city in Kurukshetra. The nest was stuffed with straws and not by Pebbles. The clutch size was 4 . It is pertinent to mention that all the four eggs hatched successfully on 24-25 May, 2011. Present observations suggest its' alarming destruction in the last 5-8 years (2003-11). Now it has been pushed in a very delicate position wherefrom its extinction in a silent manner is sure, sooner than latter.
\end{abstract}

Keywords: Egg destruction, Habitat encroachment, Kurukshetra, Threats, Yellow-wattled Lapwing

\section{INTRODUCTION}

Birds are an essential component of human inhabitations, mountains, oceans, Ice lands and virtually in each and every corner. However, few birds are characterized by their unusually veiled presence. Yellow-wattled Lapwing is one such bird. In the first place, it is inherently found in very less numbers. Moreover, an average person may take it for a Red-wattled Lapwing. In the present studies, attention is focused on this unique bird i.e. Yellow-wattled Lapwing. Moreover, attention has been focused on the crucial issue of its survival in the midst of extremely adverse conditions related urbanization and intense agriculture practices. Earlier, workers have studied Redwattled Lapwing (Kalsi and Khera, 1990 and 1992; Khajuria, 1972; Kis et al., 2000 and Gupta and Kaushik, 2011). Only few workers have so far focused attention on Yellow-wattled lapwing (Jayakar and Spurway, 1965, 1968; Dhindsa, 1983; Santharam, 1995, Sethi et al., 2010, Gupta and Kaushik, 2010). However, no one has studied Yellow-wattled Lapwing so far in Haryana in context of threats and hence the present study was undertaken.

\section{MATERIALS AND METHODS}

The study area extends to a periphery of $15-20 \mathrm{Kms}$. in the outskirts of Thanesar and Kurukshetra. The salient destinations include Sector-3, 4, 8, 30 of urban estate of
Kurukshetra. The nest studied was lodged in Sushant city on National Highway No.1 towards east. In correlation with Yellow-wattled Lapwing, only stray fields, unploughed plots, side avenues of road were surveyed.Visits were accidental without maintaining periodicity. However, having had hit upon Yellow- wattled Lapwing in a particular spot, cared vigil and affected visits were made once in a while. Such spots were listed. Careful observations in a basic manner were done to ascertain facts. The study period specifically extends to 5-8 years (2003-2011) and broadly even extend to 1986 or so in reference of atleast one spot (New Bypass going to historical Brahamsarovar-an international historical Sarovar famous for a holy dip on the occasion of solar eclipse in Kurukshetra. The camera used was Zenith 1986 model with Russian made Tele-lens.

\section{RESULTS AND DISCUSSION}

The photographic evidences crucial to the issue under discussion are available in Figs. 1-6. It is pertinent to mention that unlike Red-wattled Lapwing, Yellow wattled Lapwing is available in specific locations namely, Sushant City, Ansal Harman City and Sector-8 in Kurukshetra district. Further, it was observed that at these locations, Yellow-wattled Lapwings were found in groups of 6-8 or so and never more (Ali and Ripley, 1987). In the given conditions, Yellow-wattled Lapwings were accustomed 


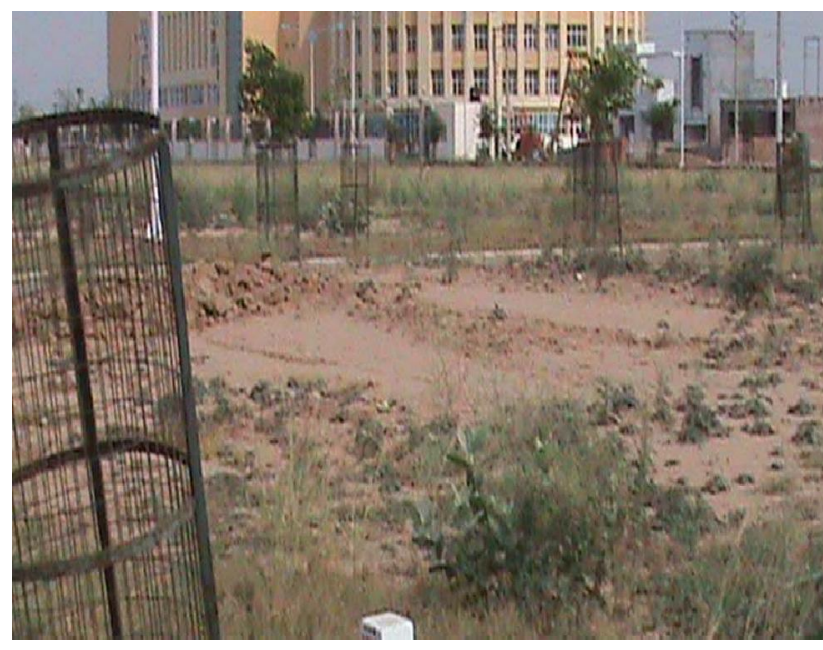

Fig. 1. A view of Sushant city in K urukshetra.

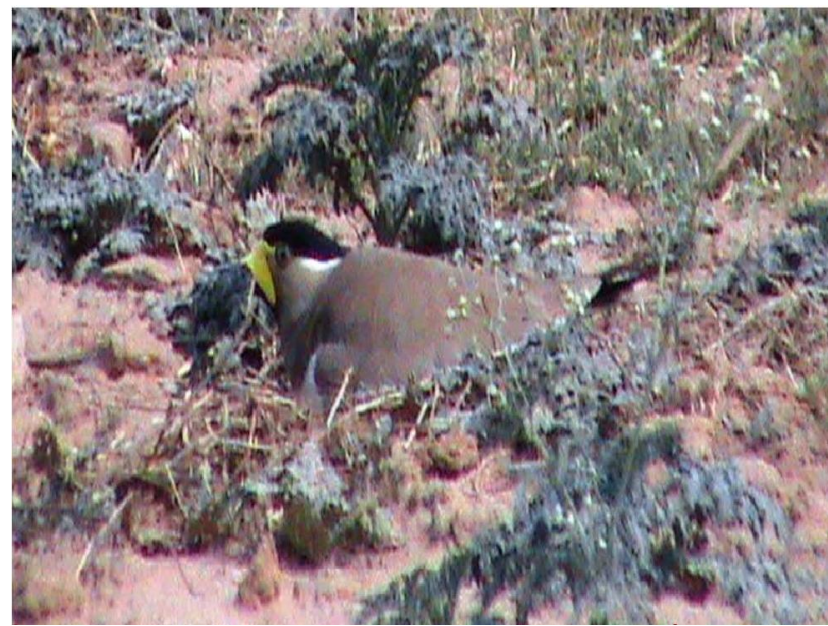

Fig. 3. Yellow wattled Lapwing busy in incubating eggs in Sushant city.

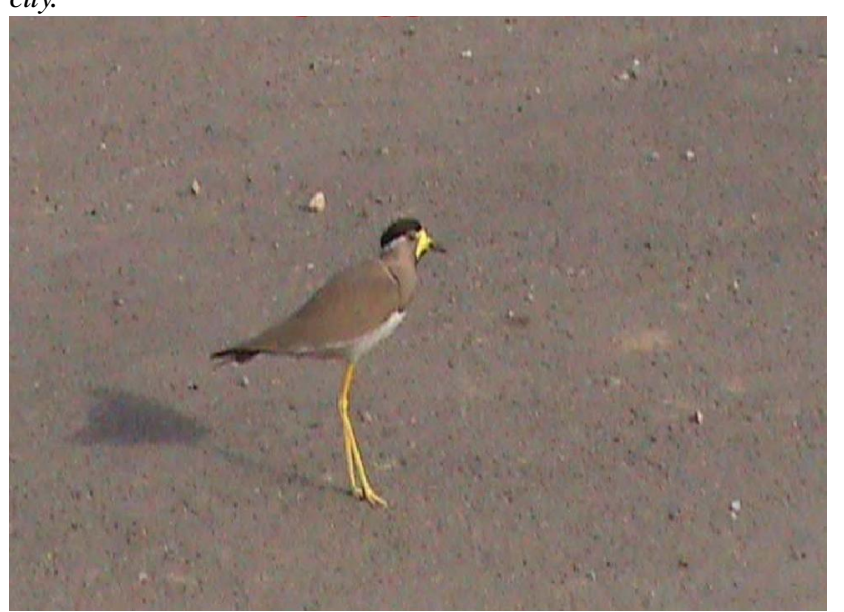

Fig. 5. Yellow-wattled lapwing running on the road as retreating in response to human intrustions.

to remain stationary. Once in a while, Yellow-wattled Lapwings were observed running in a cursory on ground as retreating in response to human intrusions. Rarely, they were seen feeding in a normal way. The various spots, namely, Sector-3, 4, 30, Jindal Chowk, New Bypass are today totally devoid of Yellow-wattled Lapwing,

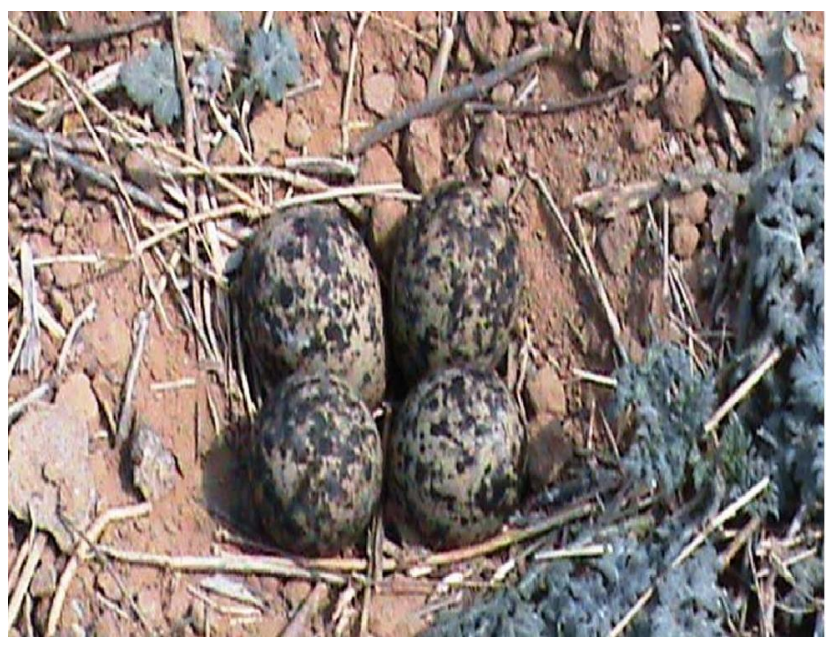

Fig. 2. Nest of Yellow wattled lapwing in the study area.

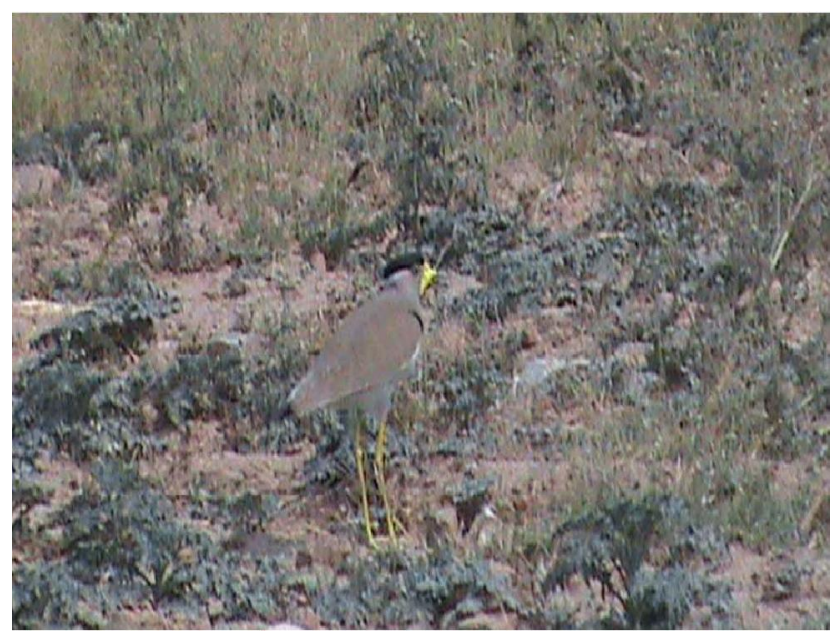

Fig. 4. Yellow wallted lapwing in sector - 4.

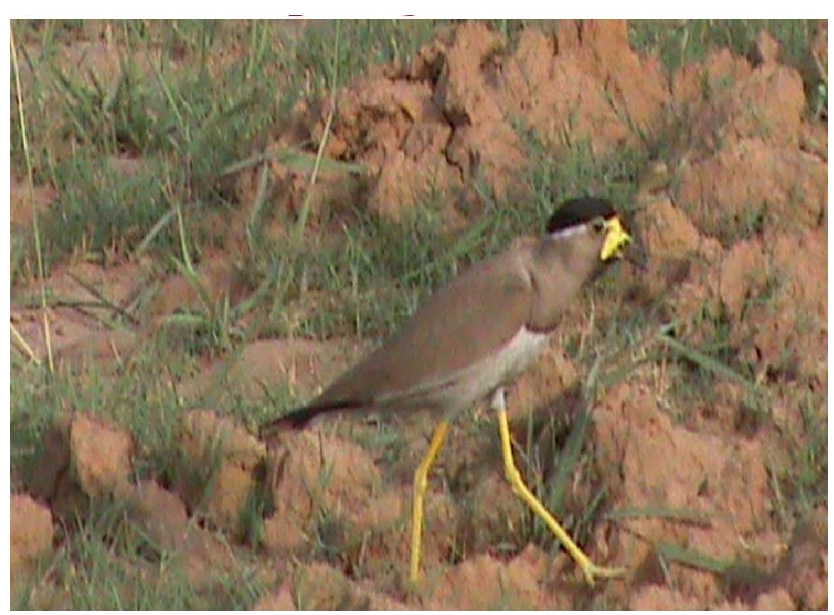

Fig. 6. Yellow-wattled lapwing emitting alarm calls in the study area.

whatsoever. Reason is expansion of human dwelling coupled with increased human intrusions. Today Yellowwattled Lapwings are restricted to Sushant City, Ansal Harmans and Sector-8 only. In contrast to urban estate of Kurukshetra, Sushant City is characterized by the interspersed patches of fields and just $2 \%$ occupancy in 
an area of 125 acres. In these circumstances, Yellowwattled Lapwing can be seen, though never in plenty. Only, one and one nest was discovered in the breeding season of 2011 on 28 April. The nest was stuffed with straws and not by Pebbles (Figs. 1-6). Males were seen in the nearby locations always. On disturbance, much resistance was not shown instead the birds fled the scene. Sethi et al. (2010) observed a fair difference in the behavior of the incubating Yellow-wattled Lapwings during different phases of their incubation period. In the present endeavour, fledglings were seen for the first time on 24 May, 2011. It is pertinent to mention that all the four eggs succeeded in hatching. The good point was the presence of small bushy summer weeds which provide very effective hiding place for the fledglings of Yellow wattled lapwing. Sethi et al. (2010) while working on the breeding biology of Yellow-wattled Lapwing in Haridwar (Uttarakhand) reported that only 16 eggs hatched successfully, out of 58 eggs in 16 nests. Jayakar and Spurway (1968) reported hatching success of 36.84 for Yellow-wattled Lapwing. As such, the present studies depict a hopeless condition in case of Yellow-wattled Lapwing. It is in great difficulty in Sushant city in Kurukshetra.

Further, these fields were ploughed for leveling purpose on 25-5-11 in Sushant city. Beautification plans will spell disaster to Yellow-wattled Lapwing in their last resort in Kurukshetra. The depletion of Yellow- wattled Lapwing in Kurukshetra certainly mirrors the ground zero situation in all parts of Haryana and Punjab including adjoining states.

Amongst other principal threats to eggs of yellow-wattled lapwing in Kurukshetra environs, natural dangers from birds of prey (Corvus splendens, Centropus sinensis, $M$ ilvus migrans) are looming large. On several occasions female Yellow wattled lapwing was observed chasing sky borne birds of prey in a very sustained and courageous manner. Rats which are in sufficient numbers constitute another serious threat. However, above all the impending dangers is the behavioural pattern of modern man. For example, in a bid to make Sushant enclave more attractive to sell off unsold plots, tractor ploughing is done in April, May and June: certainly this is the greatest danger being confronted by Yellow-wattled Lapwings and its doom's day script will be written by this very act of human beings. Ever contracting stray land pieces are related with agriculture and result into scarcity of nest laying space. Hence agriculture practices also come up as threats to the nests of Yellow-wattled lapwing in Kurukshetra. Sunflower sowing in April/May will write off Yellowwattled Lapwings in next few decades only. This hints towards one crucial conclusion that natural threats from birds of prey and jungle's rats could not destroy the eggs while being incubated by the female Yellow wattled lapwing. The threat is from the human beings. Thus harvested wheat fields in April/May/June should not be ploughed in favour of lapwings to survive and perpetuate. The onslaught on Yellow-wattled Lapwing is going on a silent manner. It is being pushed in a very difficult situation day by day and year by year. It will downgrade this bird in the ocean of oblivion in next few years hardly extending to a decade merely. Our experience in ornithology certainly hints towards its virtual extinction. Considering the difficult prevalent compounded conditions, no measures will be helpful in restoring decimated plight of Yellow-wattled Lapwing in Haryana. It is suggested that a task force of sincere ornithologists be constituted to look into the situation to save Avifauna of Haryana. The story of good birds in bad position is better described by the bad position of Yellow-wattled Lapwing.

\section{ACKNOWLEDGEMENTS}

The authors are grateful to the quest that resides in our mind and heart to observe birds in Kurukshetra.

\section{REFERENCES}

Ali, S. and Ripley, S.D. (1987). Handbook of the birds of India and Pakistan together with those of Bangladesh, Nepal, Bhutan and Sri Lanka. Compact ed. Delhi: O xford U niversity Press.

Dhindsa, M.S. (1983). Yellow-wattled Lapwing: a rare species in Haryana and Punjab. Pavo, 21(1-2), 103-104.

Fletcher, K., Warren, P. and Bains, D. (2005). Impact of nest visits by human observers on hatching success in Lapwings Vanellus vanellus: a field experiment. Bird Study, 52:221223.

Gupta, R. C. and Kaushik, T. K. (2010). On the causative factors responsible for the pathetic plight of Yellow wattled Lapwing in Kurukshetra suburbs. J ournal of Nature Conservation, 22 (2):181-187.

Gupta, R. C. and Kaushik, T.K. (2011). On the fundamentals of natural history and present threats to Red wattled Lapwing in Kurukshetra environs. J ournal of Applied and Natural Science, 3(1):62-67.

Jayakar, S.D. and Spurway, H. (1965). The Yellow wattled Lapwing Vanellus malabaricus (Boddaert), a tropical dryseason nester. II. Additional data on breeding biology. J ournal of Bombay Natural H istory Society, 62:1-14.

Jayakar, S.D. and Spurway, H. (1968).The Yellow wattled Lapwing Vanellus malabaricus (Boddaert), a tropical dryseason nester. III. Two further Seasons' breeding. J ournal of Bombay Natural History Society, 65:369-383.

Kalsi, R. S. and Khera, S. (1990). "Growth and development of the Red-wattled Lapwing Vanellus indicus". Stilt, 17: 5764.

Kalsi, R. S and Khera, S. (1992). "Some observations on maintenance behaviour of the Red-wattled Lapwing Vanellus indicus (Boddaert)". J ournal of Bombay Natural History Society, 89 (3): 368-372.

Khajuria, H. (1972). Nestlings of the Red-wattled Lapwing, Vanellus indicus (boddaert). Pavo, 8 (1-2) : 82-83. 
Kis, J., Liker A., and Szekely, T. (2000). Nest defence by Lapwings: Observations on natural behaviour and experiment. Ardea, 88:155-163.

Santharam, V. (1980). Some observations on the nests of Yellowwattled Lapwing, stone Curlew, Blackbellied Finch-Lark and redwinged Bush-Lark. N ewsletter for birdwatcher, 20 (6-7) : 5-12.

Sethi, V.K., Bhatt, D. and Kumar, A. (2010). Hatching success in Yellow-wattled Lapwing Vanellus malabaricus. Indian Birds, 5 (5):139-142. 